\title{
The Effect Of Cross Listing On The Accounting Quality Of Firms Cross Listed In East African Markets
}

\author{
Emmah W. Ndirangu, PhD Finance Student \\ Dr. Cyrus Iraya, Senior Lecturer \\ Department of Finance and Accounting, \\ University of Nairobi Nairobi, Kenya
}

doi: 10.19044/esj.2016.v12n10p403 URL:http://dx.doi.org/10.19044/esj.2016.v12n10p403

\begin{abstract}
Cross listing has been identified as a determinant of accounting quality. Prior empirical studies have differed on the effect of cross listing on accounting quality in different jurisdictions. The study of accounting quality in East Africa has however not incorporated the possible effect of cross listing. This research study sought to establish the effect that cross listing may have on the accounting quality of firms cross listed in East African stock exchanges. The study looked at three accounting quality metrics of firms cross listed in East Africa, namely, earnings management, timely loss recognition and value relevance of accounting information. The earnings management model used was the Lang, Raedy and Yetman (2003) earnings smoothing model. Timely loss recognition was investigated using the Basu (1997) model while value relevance was tested using the Lang, Raedy and Yetman (2003) model. These metrics were tested for differences during a three year period prior to cross listing and a three year period after cross listing. Accounting quality metrics for a total of six cross listed East African companies were analyzed. This study shows that earnings management did not occur around the cross listing dates. The value relevance of information presented by the cross listed firms did not change significantly, meaning that the ability of the summary accounting measures to accurately reflect the underlying economic value of the firms studied still remained as before the cross listing. There was no significant effect in terms of timely loss recognition in light of bad news and no indication of better prudence in the reporting of good news. The study finds that cross listing does not have an effect on the quality of reporting of firms cross listed within the East African Securities Exchanges.
\end{abstract}


Keywords: Accounting Quality, Cross Listing, East Africa, Securities Markets, Earnings Management, Timely Loss Recognition, Value Relevance

\section{Introduction}

Accounting quality represents the qualitative characteristics of accounting information that make it useful to users of the financial information. The salient body of literature on earnings quality does not provide a clear definition of earnings quality. It does identify, however, different attributes that are associated with or reflective of earnings quality (Givoly, Hayn \& Katz, 2008). Penman and Zhang (2002) consider highquality earnings to be sustainable earnings and, correspondingly, consider an accounting system that produces unsustainable earnings as being of poor quality. Ball and Shivakumar (2005) define reporting quality in general terms as the usefulness of financial statements to investors, creditors, managers and all other parties contracting with the firm.

Cross listing, the listing of a company's common shares on a different exchange than its primary and original stock exchange, benefits a firm in several ways, the most primary advantage being the access to more liquidity (Amihud \& Mendelson, 1986) and a greater ability to raise capital (Halling et al., 2004; Mittoo, 1992). Other benefits include the advantage of a lower cost of capital (Merton, 1987), investor protection which has given rise to the 'bonding' hypothesis (Stulz, 1999), product and labor market contemplations, and information disclosure (Baker, Nofsinger \& Weaver, 2002). Cross listing has been shown to impress investors that the firm has improved levels and quality of financial disclosure.

The investor recognition hypothesis rests on the idea that information gathering costs limit the number of different securities an investor can hold and suggests that high information gathering costs drive investors to hold a set of assets with which they are familiar (Merton, 1987). Merton (1987) also provided an addition to his basic model that indicates that changes in investor recognition will be positively correlated with corporate financing and investing activities. Improved disclosure and quality of earnings information generated by the firm is implied as a means of attaining increased investor recognition.

Amihud and Mendelson (1986)'s liquidity hypothesis states that since U.S. capital markets are very liquid, firms who cross-list can raise capital at a lower cost than at home, especially companies from emerging markets. A higher level of scrutiny in the market due to the cross listing means that the information about the company is more easily available, thus lowering the information costs to the investors and increasing the stock's visibility. Furthermore, the increase in the trading volume is accompanied by narrowed bid-ask spreads and decreased volatility; this reduces the trading 
costs even more. The listing of firms in markets with higher liquidity and the increased scrutiny by investors implies that firms willing to improve their liquidity will have to provide higher quality information.

Coffee (1999) and Stultz (1999) present that firms can raise capital if they commit to return this capital to investors and to limit the expropriation of cash-flows by controlling shareholders and managers. Therefore, firms wishing to raise external financing respond by bonding themselves to greater transparency. Coffee (2002) uses bonding to refer to a mechanism by which firms incorporated in a jurisdiction with weak protection of minority rights or poor enforcement mechanisms can voluntarily subject themselves to higher disclosure standards and stricter enforcement in order to attract investors who would otherwise be reluctant to invest. This implies that a higher quality of information is expected from firms that have listed across home borders.

Several factors have been identified to be determinants of accounting quality, both institutional and firm specific factors. Soderstrom and Sun (2007) present that the accounting standard being followed affects accounting quality. The shift to IFRS provide a better picture of the underlying economic value for firms because changes in the value of assets generally will be accounted for on a regular basis. Legal and political systems influence accounting quality in several ways (Soderstrom \& Sun, 2007). They affect accounting quality directly through enforcement of accounting standards and litigation against managers and auditors. Accounting quality is influenced indirectly by the incentives associated with financial reporting. These incentives include the development of financial markets. The demand for information from market participants provides incentives for firm managers to improve the quality of financial reporting (Francis et al., 2005).

Managers of firms whose ownership is diffuse have an incentive to increase disclosure quality in order to help shareholders in monitoring their behavior. A stronger ownership diffusion should weaken secrecy traditions (Michailesco, 1999). Companies whose shares are listed on a stock exchange are likely to offer a higher disclosure quality than non-listed firms for three reasons: listed firms have to comply with minimum disclosure requirements of market regulation authorities (Schipper, 1981); financial analysts' incentives and press coverage make listed firms increase disclosure quality to give more confidence to investors (Firth, 1979); information disclosure helps reducing agency problems increased by quotation (Cooke, 1989). Companies whose shares are listed on the domestic market and have at least one secondary listing location have to comply with domestic and foreign market requirements (Cooke, 1989), with international disclosure practices and international investors’ needs (Meek \& Saudagaran, 1990). This compliance 
is likely to increase the accounting quality of these firms relative to similar non-cross listed firms.

There have been several empirical studies to investigate the relationship between cross listing and accounting quality. Lang, Lins and Miller (2003) report that firms that cross list on U.S. exchanges have greater analyst coverage and increased forecast accuracy implying that cross-listing firms should show less earnings management due to better corporate governance and a more transparent information environment. Lang, Raedy, and Yetman (2003) find that cross-listed firms appear to engage in less earnings management (measured by earnings smoothing, accruals, and frequency of small positive earnings), report more conservative earnings (measured by timeliness of loss recognition) and are more strongly associated with share price. The differences are caused by both changes around cross-listing and differences in accounting quality before listing (Lang et al., 2003).

Lang, Raedy and Wilson (2006) found that cross listed firms present higher earnings management figures than comparable American firms. Their result corroborated the argument presented by Siegel (2005) which states that cross listing in the US does not provides the expected 'legal bonding' but only a 'reputational bonding' because the American authorities do not have the will nor the resources to enforce their requirements on foreign firms. Ndubizu (2007) found that foreign firms appear to boost accruals at the time of cross-listing their stock in the US. However, he found no differences between firms that raise capital at the time of cross-listing and a control group of cross-listing firms that do not, implying a probability of earnings management in the event of firms listing across borders. Eng and Lin (2011) found that both cross-listings and non-cross-listings show significant earnings smoothing activities and tend to use accruals to manage earnings, and are not timely in loss recognition for Chinese firms cross listed on U.S. exchanges.

\section{Research Problem}

Cross-border listing has been a topic of intensive empirical studies such as Doidge, Craig and Karolyi (2004), Karolyi (2006), and Adelegan (2009). This follows a lot of interest that researchers and academicians alike have developed towards understanding the reasons why the number of companies which have opted to cross-list their shares in foreign markets have been on the rise (Wong, Penm \& Lim, 2004).

Cross listing has also been identified as a determinant of accounting quality. Companies whose shares are listed on the domestic market with at least one foreign quotation have to comply with international disclosure practices and international investors’ needs (Meek \& Saudagaran, 1990). 
Lang, Lins and Miller (2003) and Lang, Raedy, and Yetman (2003) studied the effect of cross listing on the accounting quality of firms in the US and found that cross listed companies exhibited higher levels of quality.

Lang, Raedy and Wilson (2006), Siegel (2005), Ndubizu (2007) and Eng and Lin (2011) all investigated the consequence of cross listing on the earnings and reporting quality of firms listed in US, Hong Kong and China. They all agree on the probability that these firms exhibit more earnings smoothing than firms that are not cross listed. Eng and Lin (2011) in addition found that cross listed firms, in addition to significant earnings smoothing activities, tend to use accruals to manage earnings, and are not timely in loss recognition. Adelegan (2008) found significant positive effect in measures of stock markets depth around regional cross-listing events and emphasized the possible effect of cross listing on success variables of cross listed.

The accounting quality of East African firms has been at the heart of the adoption of the IFRSs for all the listed companies in the four securities exchanges. The use of IFRS in improving the information of firms, especially those listed was tested by Outa (2011). Findings from Outa (2011) indicate that IFRS adoption for NSE listed firms only marginally increased the accounting quality and even decreased the accounting quality of these firms. Waweru et al. (2012) found that cross listed companies were valued higher than their domestic counterparts. Onyuma et al. (2012) found that cross listing highly boosted investor confidence in East Africa. Prior studies have differed on the effect of cross listing on accounting quality. The study of accounting quality in East Africa has not incorporated the possible effect of cross listing. What would be the effect of cross listing on the accounting quality of firms trading in the East African exchanges?

\section{Objectives of the Study}

The objective of this study was to establish the effect that cross listing may have on the accounting quality of firms cross listed in East African stock exchanges. The study sought to study cross listing as a determinant of accounting quality of the firms listed in East African Securities Exchanges.

\section{Research Methodology}

This study adapted a descriptive research design to allow the establishment of an understanding of cross listing and accounting quality. The population for the study is all the listed firms in the East African Securities Exchanges namely the Nairobi Securities Exchange (NSE), Dar es Salaam Stock Exchange (DSE), Uganda Securities Exchange (USE) and Rwanda Stock Exchange (RSE). The focus of the study was the cross listed firms in these exchanges. The firms selected for the study must have had 
their first secondary listing on or before the year 2010 to allow for collection of adequate financial measures.

There are a total of nine cross listed East African companies namely Kenya Commercial Bank, Nation Media Group, Centum Investments Limited, Umeme Limited, Jubilee Holdings Limited, Equity Bank Limited, East Africa Breweries Limited, Uchumi Limited and Kenya Airways. Uchumi and Umeme Limited are excluded from the study because their first cross border listing dates were 2013 and 2012 respectively. Data was collected for six firms out of seven, with pre cross listing information on East African Breweries not being accessible.

Quantitative methods were used to collect secondary data related to financial reporting including revenues, income, balance sheet and cash flow data. The focus was on the financial data that relates to the models of analysis. The data collected focused on three measures of accounting quality collected over a six year period for each firm. The six year period was an equal split between the pre cross listing period and the post cross listing period. The objective was achieved by analysis of financial information obtained from the firms' financial reports for three years prior to and after the cross listing. The analysis was based on three dimensions of accounting quality namely earnings management, timely loss recognition and value relevance of the cross listed firms.

Barth et al. (2007) argue that the metrics of accounting quality reflects the effects of the financial reporting system as well as those attributable to financial reporting such as the economic environment. Barth et al. (2007) argued that there is no definitive way to determine the degree to which these research design features mitigate the effects of the economic environment and incentives on the metrics. It is expected that because all firms listed in the four exchanges must be IFRS compliant controlled for these effects.

The metrics applied to measure accounting quality in the study cover three dimensions as below:

Earnings smoothing, as a measure of earnings management, was checked using the Spearman partial correlation between the residuals of operating accruals and operating cash flows (Lang, Raedy and Yetman, 2003; Leuz, Nanda and Wysocki, 2003; Myers \& Skinner 1999).

$\mathrm{CF}_{\text {it }}=\mathrm{a}_{0}+\mathrm{a}_{1}$ SIZE $_{\mathrm{it}}+\mathrm{a}_{2} \mathrm{GROWTH}_{\mathrm{it}}+\mathrm{a}_{3}$ EISSUE $_{\mathrm{it}}+\mathrm{a}_{4} \mathrm{LEV}_{\mathrm{it}}+\mathrm{a}_{5}$ DISSUE $_{\mathrm{it}}+$ $\mathrm{a}_{6}$ TURN $_{\text {it }}+\mathrm{a}_{7} \mathrm{CF}_{\text {it }}+\mathrm{a}_{8} \mathrm{AUD}_{\mathrm{it}}+\mathrm{a}_{9} \mathrm{NUMEX}_{\mathrm{it}}+\mathrm{a}_{10} \mathrm{XLIST}_{\mathrm{it}}+\mathrm{a}_{11} \mathrm{CLOSE}_{\mathrm{it}}+\varepsilon_{\text {it }}$ (Equation 1)

$\mathrm{ACC}_{\mathrm{it}}=\mathrm{a}_{0}+\mathrm{a}_{1}$ SIZE $_{\mathrm{it}}+\mathrm{a}_{2} \mathrm{GROWTH}_{\mathrm{it}}+\mathrm{a}_{3}$ EISSUE $_{\mathrm{it}}+\mathrm{a}_{4} \mathrm{LEV}_{\mathrm{it}}+\mathrm{a}_{5}$ DISSUE $_{\mathrm{it}}+$ $\mathrm{a}_{6}$ TURN $_{\text {it }}+\mathrm{a}_{7} \mathrm{CF}_{\text {it }}+\mathrm{a}_{8} \mathrm{AUD}_{\mathrm{it}}+\mathrm{a}_{9} \mathrm{NUMEX}_{\mathrm{it}}+\mathrm{a}_{10} \mathrm{XLIST}_{\mathrm{it}}+\mathrm{a}_{11} \mathrm{CLOSE}_{\mathrm{it}}+\varepsilon_{\mathrm{it}}$ (Equation 2)

Where: 
$\mathrm{CF}_{\text {it }}$ is the annual cash flow from operating activities scaled by end of year total assets for firm i year $t$,

$\mathrm{ACC}_{\mathrm{it}}$ is the earnings less cash flow from operating activities (scaled by end of year total assets) for firm i year $t$,

SIZE is the natural logarithm of end of year market value of equity,

GROWTH is percentage change in sales,

EISSUE is percentage change in common stock,

LEV is end of year total liabilities divided by end of year equity book value,

DISSUE is percentage change in total liabilities,

TURN is sales divided by end of year total assets, CF is annual net cash flow from operating activities,

AUD is an indicator variable that equals one if the firm's auditor is PwC, KPMG, EY, or Deloitte, and zero otherwise,

NUMEX is the number of exchanges on which a firm's stock is listed,

XLIST is an indicator variable that equals one if the firm is listed on any US stock exchange and World Scope indicates that the US exchange is not the firm's primary exchange (not applicable for this study), and

CLOSE is the percentage of closely held shares of the firm as reported by World Scope (not applicable for this study)

Timely loss recognition relates to an organization's ability to recognize losses as they occur by not engaging in activities that reschedule the losses to other periods (Outa, 2011). The regression specification used was the Basu (1997) model. Basu (1997) regresses accounting earnings (EPS/P) on stock returns (R) separately for 'good-news' and 'bad-news' firm-year observations. A firm-year is deemed as a 'good-news' firm-year, if its market return is positive or zero, i.e. $\mathrm{R}_{\mathrm{it}} \geq 0$. Conversely, a firm-year is deemed as a 'bad-news' firm-year, if its stock return is negative, i.e. $\mathrm{R}_{\mathrm{it}}<0$. The estimated slope coefficient measures how timely the news embodied in the stock return is recognized in earnings, conditional on the sign of stock returns. The model is as below:

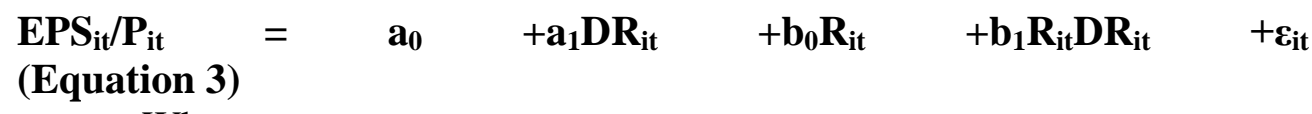

Where:

EPS $_{\text {it }}$ is Earnings per share for firm i year $t$,

$\mathrm{P}_{\text {it }}$ is opening stock market price for firm $\mathrm{i}$ year $\mathrm{t}$,

$\mathrm{R}_{\mathrm{it}}$ is Stock markets return for firm i year $\mathrm{t}$,

$\mathrm{DR}_{\mathrm{it}}$ is Dummy variable that is equal to 1 if the stock market return for firm $\mathrm{i}$ in year $\mathrm{t}$ is negative, and equal to 0 if the stock market return for firm $\mathrm{i}$ in year $\mathrm{t}$ is non- negative. 
Value relevance is the ability of the summary accounting measures to reflect the underlying economic value of the firm. These are measured through contemporaneous stock prices. Value relevance tries to associate a firm's value as expressed in stock prices to the reported income statement and balance sheet (Outa, 2011). Firms with higher quality earnings have a higher association between stock prices and earnings and equity book value because higher quality earnings better reflect a firm's underlying economics (Barth, Beaver, and Landsman, 2001).

The value relevance measure was the adjusted $R^{2}$ from equation:

$\mathbf{P}_{i t}=\mathbf{b}_{0}+\mathbf{b}_{1}$ BVEPS $_{i t}+\mathbf{b}_{2}$ NIPS $_{\text {it }}+\varepsilon_{\text {it }}$

\section{(Equation 4)}

Where:

$\mathrm{P}^{*}{ }_{\mathrm{it}}$ is the price as of 6 months after fiscal year end

BVEPS is the book value of equity per share

NIPS is the net income per share

The study tested the effect of cross listing on accounting quality by determining the difference of means of the measures of accounting quality in the pre-cross listing and post-cross listing period. The pre listing period tested was three years before the firm was first listed on a secondary exchange. The post listing period tested covered three years after the firm was first listed on another country's exchange. Each of the accounting quality measures was computed for each firm in the pre and post cross listing period and descriptive statistics computed for the pre and post cross listing periods. Then a two sample t-test was carried to test the differences between the computed accounting quality metrics.

\section{Results of Research and Discussion Earnings Management}

The Spearman partial correlation between the residuals of operating accruals and operating cash flows as tested by the regression equations above was computed as below:

\begin{tabular}{|c|c|c|}
\hline \multicolumn{3}{|c|}{ Spearman Correlation Between the Residuals of Operating Cash flows and Operating Accruals } \\
\hline & Pre Cross Listing & Post Cross Listing \\
\hline Kenya Commercial Bank (KCB) & -0.72 & 0.54 \\
\hline Nation Media Group (NMG) & -0.5 & -0.995 \\
\hline Centum Investments Limited & 0.87 & 0.2774 \\
\hline Jubilee Holdings Limited (JBL) & -0.99 & -0.81 \\
\hline Equity Bank Limited & -1 & -0.816 \\
\hline Kenya Airways (KQ) & 0.64 & 0.97 \\
\hline & T-Stat & -0.52918 \\
\hline & P-value & 0.30966 \\
\hline
\end{tabular}

Source: Research Findings

Firms with less earnings smoothing exhibit a more negative correlation between accruals and cash flows (Lang, Raedy \& Yetman, 2003). 
The general trend in the research findings indicate a move towards positive correlation after the cross listing. Four of the six firms indicate a likely possibility of earnings smoothing. The biggest difference in the pre and post cross listing period is from -0.72 to 0.54 . The mean movement in correlation shows an overall change in the correlation towards the positive, that is, from -0.28 to -0.14 . The change in correlation is not significant as tested by the tvalue and p-value $(>0.05)$, indicating no possible earnings smoothing, thus no change in accounting quality after cross listing.

\section{Timely Loss Recognition}

Basu (1997) regresses accounting earnings (EPS/P) on stock returns, $\mathrm{R}$, separately for good news and bad news firm year observations. The results of the analysis are represented in the table below:

\begin{tabular}{|c|c|c|c|c|}
\hline \multicolumn{5}{|c|}{ Slope Coefficients as per the Basu (1997) model } \\
\hline & \multicolumn{2}{|c|}{ Pre Cross Listing } & \multicolumn{2}{|l|}{ Post Cross Listing } \\
\hline & Good News & Bad News & Good News & Bad News \\
\hline & $\square \mathbf{0}$ & $\square \mathbf{1}$ & $\square \mathbf{0}$ & $\square 1$ \\
\hline Kenya Commercial Bank (KCB) & 0.000344 & - & 0.13463 & 0.004007 \\
\hline Nation Media Group (NMG) & 0.00376 & 0.000165 & 0.00144 & 0.004728 \\
\hline Centum Investments Limited & - & 0.0001944 & 0.016097 & 0.00386 \\
\hline Jubilee Holdings Limited (JBL) & 0.009263 & - & 0.000736 & 0.001197 \\
\hline Equity Bank Limited & 0.002813 & - & 0.01171 & 0.0055 \\
\hline Kenya Airways (KQ) & 0.71726 & - & 0.03913 & - \\
\hline & & & $\begin{array}{l}\text { t-stat (good news) } \\
\text { t-stat (bad news) }\end{array}$ & $\begin{array}{l}0.73608 \\
-3.6635\end{array}$ \\
\hline & & & $\begin{array}{l}\text { p-value (good news) } \\
\text { p-value (bad news) }\end{array}$ & $\begin{array}{l}0.24737 \\
0.00727 \\
\end{array}$ \\
\hline
\end{tabular}

Source: Research Findings

The firms return a lower coefficient for most of the good and bad news observations. The changes are significant for the 'bad news' observations, $\mathrm{p}<0.05$. The 'good news' indicate a lower coefficient on the earnings response to good news, that is not significant as $\mathrm{p}>0.05$. This shows that the firms tend to be timelier in the recognition of good news. It is however evident form the analysis that bad news are not recognized in a timely manner. It can however not be concluded that cross listed firms are less conservative in their loss recognition due to this. Only two firms were involved in the measure of the Basu asymmetric timeliness coefficient for bad news. The analysis returns the effect of cross listing on timely loss recognition by firms as indifferent.

\section{Value Relevance}

Value relevance of reported financial information, as the ability of summary accounting measures to reflect the underlying economic value of the firm, was measured using the adjusted $r^{2}$ using the model above. 


\begin{tabular}{|c|c|c|}
\hline \multicolumn{3}{|c|}{ Adjusted $\mathbf{r}^{2}$ as a measure of value relevance of reported financial information } \\
\hline & Pre Cross Listing & Post Cross Listing \\
\hline Kenya Commercial Bank (KCB) & 0.9705 & 0.913 \\
\hline Nation Media Group (NMG) & 0.87772 & 0.94735 \\
\hline Centum Investments Limited & 0.59694 & 0.98206 \\
\hline Jubilee Holdings Limited (JBL) & 0.99794 & 0.68156 \\
\hline Equity Bank Limited & 0.99788 & 0.95657 \\
\hline Kenya Airways (KQ) & 0.97218 & 0.06234 \\
\hline & t-stat & 0.810897 \\
\hline & p-value & 0.227138 \\
\hline
\end{tabular}

Source: Research Findings

The metrics for value relevance are the explanatory powers of income and equity book value for prices. Higher explanatory power is seen as evidence of more value relevance. Four of the six firms indicate a reduction in adjusted $\mathrm{r}^{2}$ after cross listing. The most significant individual firm reduction in adjusted $r^{2}$ is 0.06 from 0.97 . There is a mean reduction in the adjusted $\mathrm{r}^{2}$ for all firms from 0.9 to 0.76 , which is not significant as $\mathrm{p}>0.05$.

Michaïlesco (1999) stated multiple listing status as a determinant of accounting quality. Lang, Lins and Miller (2003) findings suggest that cross listing firms are expected to show less earnings management due to better corporate governance and a more transparent information environment. Lang, Raedy and Wilson (2006) concluded that cross listed firms in the United States present higher earnings management figures relative to comparable American firms. In East Africa, this study has indicated that there was no significant effect of cross listing on earnings management by the firms cross listed in East African securities markets. There was no significant effect of cross listing on the accounting quality of East African firms.

Lang, Raedy and Yetman (2003), in their study, concluded that cross listed firms have better accounting quality. They found that cross listed firms appear to engage in less earnings management, report more conservative earnings and are more strongly associated with share prices. Eng and Lin (2011) found that cross listing did not change the accounting choices of Chinese cross listing firms. The findings of this study are more consistent with those of Eng and Lin (2011) in that East African firms show no significant change in their accounting quality East African cross listed firms have reported no change in earnings management, timely loss recognition and value relevance.

\section{Conclusion}

This study investigated three dimensions of accounting quality namely earnings management, timely loss recognition and value relevance by comparing these measures in the three year period prior to cross listing and the three year period after cross listing in East African markets. The 
information was obtained from the financial reports as well as relevant and available market information for six cross listed whose information was available for analysis.

Earnings management was measured by determining the Spearman partial correlation between the residuals of operating accruals and operating cash flows. Firms with less earnings smoothing exhibit a more negative correlation between accruals and cash flows (Lang, Raedy \& Yetman, 2003). The mean movement in correlation shows an overall change in the correlation towards the positive from -0.28 to -0.14 . This change was however found to be non-significant as indicated by the p-value $(<0.05)$, indicating no evidence of earnings smoothing.

Timely loss recognition is measured using Basu's (1997) conservatism model. The good news and bad news recognition was measured separately. The 'good news' indicate a lower coefficient on the earnings response to good news. This change is however not significant. This indicates that firms exhibited no change in the recognition in the timely recognition of good news prior to and after cross listing. The changes are significant for the 'bad news' observations as indicated by $\mathrm{p}<0.05$. The change was concluded not to be significant for the study because of the smaller number of firms that reported bad news within the period reviewed. The analysis thus returns the effect of cross listing on timely loss recognition, which is bad news, by firms as indifferent.

Value relevance is measured in the study by determining the response of earnings on returns. There is a mean reduction in the adjusted $r^{2}$ for all firms from 0.9 to 0.76 , which is not significant as $\mathrm{p}$ is greater than 0.05 . This result indicates that value relevance has not changed for the firms after cross listing. The three metrics for accounting quality indicated that there was no significant change in accounting quality prior to and after the cross listing.

The empirical evidence of this study shows that earnings management did not occur around the cross listing dates. The value relevance of information presented by the cross listed firms did not change significantly, meaning that the ability of the summary accounting measures to accurately reflect the underlying economic value of the firms studied still remained as before the cross listing. There was no significant effect in terms of timely loss recognition in light of bad news and no indication of better prudence in the reporting of good news.

The findings of the study present evidence on the effect of cross listing on the accounting quality of firms cross listed within the East African Securities Exchanges. Previous studies have indicated differed effects of cross listing on the accounting quality of cross listed in different regions. Based on the findings of the study, it is clear that cross listing does not have 
an effect on the quality of reporting of firms cross listed within the East African Securities Exchanges.

\section{Recommendations for Further Research}

It would be very important to have other studies focus on the other determinants of accounting quality with regard to the East African context, especially the financial reporting incentives, ownership structure, external financing and other firm specific factors. This will expand the literature on the usefulness of financial information in East Africa.

Another possible area of research would be a study of why there are only a few number of firms that have chosen to cross list in East Africa, despite the easing of regulations and the increased effort towards regional financial integration. Researchers should continue to investigate and outline the future of cross listing in East Africa, as well as the continued efforts towards higher financial accountability in the region.

\section{References:}

Adelegan, O. (2009). The Impact of the Regional Cross-Listing of Stocks on Firm Value in Sub-Saharan Africa. International Monetary Fund. Washington: IMF Working Paper 09/99.

Adelegan, O. J. (2008). Can regional cross-listings accelerate stock market development? Empirical evidence from Sub-Saharan Africa. International Monetary Fund. Washington: IMF Working Paper.

Amihud, Y., \& Mendelson, H. (1986). Asset prices and the bid ask spread. Journal of Financial Economics, 17, 223-249.

Baker, H., Nofsinger, R., \& Weaver, D. (2002). International cross-listing and visibility. Journal of Financial and Quantitative Analysis 37 (3), 495521.

Ball, R., \& Shivakumar, L. (2005). Earnings quality in U.K. private firms: Comparative loss recognition timeliness. Journal of Accounting and Economics 39, 83-128.

Barth, M. E., Landsman, W. R., Lang, M., \& Williams, C. (2007). Accounting Quality: International Accounting Standards and US GAAP. Stanford University Graduate School of Business Research Paper No. 1976.

Barth, M., Landsman, W., \& Lang, M. H. (2008). International accounting standards and accounting quality. Journal of Accounting Research 46(3), 467-498.

Basu, S. (1997). The conservatism principle and the asymmetric timeliness of earnings. Journal of Accounting and Economics 24 (1), 3-37.

Coffee Jr., J. C. (1999). The Future as History: The Prospects for Global Convergence in Corporate Governance and its Implications. Northwestern Law Review (93), 641-707. 
Coffee Jr., J. C. (2002). Racing Towards the Top? The Impact of CrossListings and Stock Market Competition on International Corporate Governance. Columbia Law Review (102), 1757-1831.

Cooke, T. (1989). An empirical study of financial disclosure by Swedish companies. New York: Garland.

Doidge, C., Karolyi, A., \& Stulz, R. (2004). Why Are Foreign Firms Listed in the U.S. Worth More? Journal of Financial Economics 71, 205-238.

Eng, L. L., \& Lin, Y. (2011, February). Accounting Quality, Earnings Management and Cross-listings: Evidence from China.

Firth, M. (1979). The impact of size, stock market listing and auditors on voluntary disclosure in corporate annual reports. Accounting and Business Research, 9, 273-280.

Francis, J., LaFond, R., Olsson, P., \& Schipper, K. (2005). The market pricing of accruals quality. Journal of Accounting and Economics, 39(2), 295-327.

Givoly, D., Hayn, C., \& Katz, S. P. (2008). Does Public Ownership of Equity Improve Earnings Quality? Harvard Business School Working Paper, 09-105.

Halling, M., Pagano, M., Randl, O., \& Josef, Z. (2004). Where is the market? Evidence from Cross Listings. CEPR Discussion Paper No. 4987.

Karolyi, A. (2006). The World of Cross-Listings and Cross-Listings of the World: Challenging Conventional Wisdom. Review of Finance 10, 99-152.

Lang, M., Lins, K., \& Miller, D. (2003). ADRs, Analysts, and Accuracy: Does Cross Listing in the United States Improve a Firm's Information Environment and Increase Market Value? Journal of Accounting Research 41, 317-345.

Lang, M., Raedy, J., \& Wilson, W. (2006). Earnings management and cross listing: Are reconciled earnings comparable to U.S. earnings? Journal of Accounting and Economics 42, 255-283.

Lang, M., Raedy, J., \& Yetman, M. (2003). How representative are firms that are cross-listed in the United States? An analysis of accounting quality. Journal of Accounting Research 41-2, 363-386.

Leuz, C., Nanda, D., \& Wysocki, P. (2003). Earnings management and investor protection: An international comparison. Journal of Financial Economics 69, 505-527.

Leuz, C., Nanda, D., \& Wysocki, P. (2003). Earnings management and investor protection: An international comparison. Journal of Financial Economics 69, 505-527.

Meek, G., \& Saudagaran, S. (1990). A survey of research on financial reporting in a transnational context. Journal of Accounting Literature, 9, 145-182. 
Merton, C. (1987). A simple model of capital market equilibrium with incomplete information. Journal of Finance 42(3), 483-504.

Michaïlesco, C. (1999). The determinants of the quality of accounting information disclosed by French listed companies. 1999 EAA Congress.

Mittoo, U. (1992). Managerial Perceptions of the Net Benefits of Foreign Listing: Canadian Evidence. Journal of International Financial Management and Accounting 4, 40-62.

Ndubizu, G. (2007). Do cross-border listing firms manage earnings or seize a window of opportunity? The Accounting Review 82, 1009-1030.

Onyuma, S. O., Mugo, R. K., \& Karuiya, a. J. (2012). Does Cross Border Listing (Still) Improve Firm Financial Performance in East Africa? Journal of Economics, Business and Finance, 92-109.

Ormrod, P., \& Taylor, P. (2004). The impact of the change to International Accounting Standards on debt covenants: a UK perspective. Accounting in Europe, 1, 71-94.

Outa, E. R. (2011). The Impact of International Financial Reporting Standards (IFRS) Adoption on the Accounting Quality of Listed Companies in Kenya. International Journal of Accounting and Financial Reporting, 1(1), 212-241.

Penman, S. H., \& Zhang, X. J. (2002). Accounting conservatism, the quality of earnings, and stock returns. The Accounting Review 77 (2), 237-264.

Schipper, K. (1981). Discussion of voluntary corporate disclosure: the case of interim reporting. Journal of Accounting Research, $n^{\circ} 19$, supplement, 8588.

Siegel, J. (2005). Can foreign firms bond themselves effectively by renting U.S. securities laws? Journal of Financial Economics, 75, 319-359.

Soderstrom, N., \& Sun, K. (2007). IFRS adoption and Accounting Quality: A Review. European Accounting Review, 16(4), 675-702.

Stulz, R. (1999). Globalization, Corporate Finance and the Cost of Capital. Journal of Applied Corporate Finance (12), 8-25.

Waweru, K. M., Pokhariyal, G. P., \& Mwaura, M. F. (2012, September). Cross-Listing and Valuation Effects: Evidence from Nairobi Securities Exchange. Journal of Modern Accounting and Auditing, 8(9), 1371-1380.

Wong, K. W., Penm, J., Terrell, R. D., \& Lim, K. (2004). The Relationship between Stock markets of major developed countries and Asian emerging markets. Journal of Applied Mathematics and Decision Sciences, 8(6), 201218. 